\title{
The Adoption of Process Standards for Teaching Economics: A Lesson from High School Economics Teachers
}

\author{
Amiruddin ${ }^{1}$, Amrusi $^{2}$ \\ \{amiruddin@unsyiah.ac.id ${ }^{1}$ \} \\ ${ }^{1,2}$ Department of Economic Education, Universitas Syiah Kuala, Aceh, Indonesia
}

\begin{abstract}
This study discusses the adoption of processes standard for teaching in economic teaching in high schools in the Municipality of Banda Aceh, Indonesia. The population in this study were all economics teachers and a sample of twenty-one respondents. Based on the results of the study indicate that in general, the teacher has applied the standard of the teaching process well in the teaching and teaching process. First, the activities carried out by the teacher during the first lesson are included in both categories. Second, the teacher's activity in the next stage is to do the teaching. Third, activities that are always carried out by teachers in closing teaching in school are doing reflection or evaluation with students in their investigations, evaluating the whole set of teaching activities and results obtained by students, helping students find the benefits of teaching outcomes.
\end{abstract}

Keywords: adoption of standard processes, teacher perceptions, economic teaching

\section{Introduction}

Teacher performance is the leading indicator of education quality. Good education only happens if every teacher can optimize the achievements that can be done by students with their potential. Efforts to optimize achievement under the potential of students require continuous renewal efforts because in a changing teaching environment, each student is unique, and science continues to develop. These developments or changes require teachers to innovate so that the experiences of students and new teaching resources can continue into the economic teaching process.

Public education continues to experience changes trying to adjust to the demands of the times. Changes in the field of education appear to be accelerating since the enactment of Law Number 20 of 2003 concerning the National Education System [1]. Most of the changes stated in the legislation contain various innovations in teaching. These laws include: (a) Government Regulation Number 19 of 2005 concerning National Education Standards, (b) Regulation of the Minister of National Education of the Republic of Indonesia Number 22 of 2006 concerning Content Standards for Secondary Primary Education Units, (c) Regulation of the Minister of National Education Republic of Indonesia Number 41 of 2007 concerning Process Standards for Primary and Secondary Education Units, (d) Regulation of the Minister of National Education of the Republic of Indonesia Number 20 of 2007 concerning Education Assessment Standards. Various innovations have been carried out by the government and 
other organizers, but lively innovation does not automatically improve the quality of education. In this regard, Aceh Province is one of the provinces that tries to improve the quality of education from time to time. It appears in the vision of the Government of Aceh, which reads Aceh Carong (Aceh Smart). From the formulation of the vision, it appears that human resources as the basis of community excellence.

Economic Subjects is one of a minimum of 16 subjects in class X given a time allocation of 2 hours and 4 hours for classes XI and XII. Although given in minimal time allocation, however, economic subjects have a very strategic meaning. Zizek (2010) reminds that today's market logic and competition have progressively pushed itself into a hegemonic ideology[2]. Then the economy will be understood as the basis of the primary considerations and at the same time an indicator of a nation. Thus, it becomes an important task to formally introduce economics, namely the High School of Higher Education.

Pedagogical competencies that are directly related to teaching in front of the class are not satisfactory. Innovations in the form of government policies relating to this are the Minister of National Education Regulation of the Republic of Indonesia Number 41 of 2007 concerning Process Standards for Primary and Secondary Education Units [3]. In this ministerial regulation, four things arranged: planning of the teaching process, the process of implementing teaching, evaluating teaching outcomes, and monitoring the teaching process.

Various innovations in the form of various policies from the government do not directly improve the quality of education. Various forms of education policy diffusion will not be meaningful unless they are balanced with an adequate level of acceptance. Various variables will determine the level of acceptance. The level of policy acceptance or innovation will be determined by how intensive the diffusion process is carried out. It is also influenced by factors that exist in the recipient, namely the cognitive structure that already exists, the level of one's education affects the level of acceptance. Rogers revealed several related variables [4]. These variables are attributes that exist in new policies that include (1) relative advantage, (2) compatibility, (3) complexity, (4) trialability, and (5) observability. besides that, it is still influenced by other variables which include (1) types of innovation decisions, (2) nature of communication channels, (3) nature of the social system, and (4) stands for the extent of change agents' promotion efforts [4]. The above considerations then this paper will discuss the literature review in the second section, methodology in the third section, results, and discussion in the fourth section, and conclusions in the fifth section.

\section{Literature review}

\subsection{Standardisation of the teaching process}

Efforts to improve the quality of education have always been recognized as one of a series of strategies in improving the quality of life of the nation. Improving the quality of education is pursued in various ways. One of the methods taken is the standardization of education. Education standardization is a policy that is considered appropriate given that Indonesia is a country in which it has a multidimensional plurality. For this reason, a standard is needed to regulate a minimum of educational services. Standards are not to impede development but to spur improvement in the quality of education. With the Government Regulation Number 19 of 2005 concerning National Education Standards, the practice of education in Indonesia is carried out on the standards set by the government. National education standards are the minimum criteria regarding the education system in the entire jurisdiction of the Unitary Republic of Indonesia. It regulates eight components which include (1) content standards, (2) process standards, (3) graduate competency standards, (4) educator and education staff 
standards, (5) facilities and infrastructure standards, (6) management standards, (7) financing standards, and (8) education assessment standards [5].

Among the components in education standards, which are components that are directly related to teacher performance in real terms, the teacher in front of the class is the process standard. The process standard is stated in the Regulation of the Ministry of National Education of the Republic of Indonesia Number 41 of 2007 concerning Process Standards for Elementary and Secondary Education Units [3]. Process standards are national education standards relating to the implementation of teaching in an educational unit to achieve graduate competency standards. Process standards include planning the teaching process, implementing the teaching process, evaluating teaching outcomes, and monitoring the teaching process for the implementation of an effective and efficient teaching process.

In the standard process, it is revealed that one of the principles of education is the process of civilizing and empowering students that lasts a lifetime. In the process, the teacher is required to be not only able to teach but also be able to set an example, build a will, and develop the potential and creativity of students. The implication of this principle is a shift in the educational process paradigm, namely from the teaching paradigm to the teaching paradigm. Teaching is the process of student interaction with the teacher and teaching resources in a teaching environment. The teaching process needs to be planned, implemented, assessed and monitored to be carried out effectively and efficiently.

\subsection{Teaching process planning}

Teaching process planning includes a syllabus and lesson plan containing subject identity, competency standards, essential competencies, indicators of achievement of competencies, teaching objectives, teaching materials, time allocation, teaching methods, teaching activities, assessment teaching outcomes, and teaching resources. The syllabus as a reference for the development of the contains the identity of the subject or theme of the lesson, teaching material, teaching activities, indicators of competency achievement, assessment, time allocation, and teaching resources.

The teaching implementation plan is spelled out from the syllabus to direct learners' teaching activities to reach. Every teacher in the education unit is obliged to compile lesson plans thoroughly and systematically so that teaching takes place interactively, inspiration, fun, challenging, motivating students to participate actively, as well as providing sufficient space for initiative, creativity, and independence in accordance with their talents, interests, and physical as well as psychological development of students [3].

\subsection{Implementation of the teaching process}

This section regulates the requirements for implementing the teaching process, which includes the provisions of (1) teaching groups, (2) minimum workload of teachers, (3) textbooks, and (4) classroom management. In classroom management, for example, teachers are required to arrange seats according to the characteristics of students and subjects, as well as teaching activities to be carried out. The teacher must also adjust the subject matter with the speed and teaching ability of students. Many other things are regulated in this section.

The implementation of teacher teaching always organizes teaching in three phases, namely the preliminary activity phase, the core activity phase, and the Closing Activity phase. In the preliminary phase of the teacher's work, for example, preparing students psychologically and physically to participate in the teaching process, and asking questions that relate prior knowledge to the material to be learned. In the core activities, teachers are expected to use methods that are tailored to the characteristics of students and subjects, which can include the 
process of exploration, elaboration, and confirmation. In closing activities, the teacher does activities such as conducting assessments and/or reflections on activities that have been carried out consistently and programmed.

The standard process also addresses the issue of assessment. Assessment is carried out by the teacher of teaching outcomes to measure the level of achievement of students' competencies and is used as material for preparing progress reports on teaching outcomes and improving the teaching process. The standard explained that the assessment is carried out consistently, systematically, and programmed using tests and non-test in written or oral form, performance observation, attitude measurement, assessment of the work in the form of assignments, projects or products, portfolios, and self-assessment. The ins and outs of the assessment are not explained in detail in this standard because it is regulated in the assessment standards [3].

\subsection{Innovation adoption theory}

One innovation in the teaching process is innovation that comes from the government in the form of regulations. The government diffuses these regulations that can be binding or can also be recommended. Diffusion is defined as a process in which an innovation is communicated through specific channels over a certain period to members of a social system [4]. Meanwhile, innovation is defined as an idea, practice or object that is considered as something new by an individual or another adoption unit [4]. Then the diffusion process requires prerequisites for innovation first. Diffusion can also be said as a select type of communication where the message is a new idea. Besides, diffusion can also be considered as a type of social change that is a process of change that occurs in the structure and function of social systems. The main objective of the diffusion process is the adoption of an innovation by members of a particular social system. Members of the social system can be individuals, informal groups, organizations and or sub-systems.

The response from defusion can be in the form of rejection or acceptance or adoption. Adoption of innovation can be short-lived but can also be slow. The relative speed of innovation adopted by members of the social system is called the rate of adoption. The concept of adoption rate is a general measure that refers to the number of individuals who adopt a new idea at a specific time, for example, every year [4]. The Perception attribute of innovation is an essential explanation of the level of innovation adoption. Five attributes can explain about 49 to 87 percent of the variance in adoption rates: relative advantage, compatibility, complexity, trialability, and observability. In addition to the other variables are (1) types of innovation decisions, (2) the nature of communication channels diffusion at various stages of the innovation-decision process, (3) the nature of the social system where innovation is fused, (4) extent of change agents' promotion efforts [4].

Halimah et al. research on the development of the Education Unit Level curriculum design model that refers to the National Education Standards show that in the process of its implementation, research and development form a cycle, which begins by conducting a preliminary study to find an initial product framework [6]. The initial product is developed in a particular situation, and through a trial, the results of which are then revised and retried so that in the end a final product is deemed perfect, and then the product is tested for validation.

\section{Method}

The formulation of the problems of this study, this research is to use a combination of quantitative and qualitative approaches, which are often referred to as mixed methods [7]. By 
considering the research problem, a sequential explanatory strategy will be chosen [7]. This strategy has a flow of departure from a quantitative approach and continued with a qualitative approach. This strategy is applied by the collection and analysis of quantitative data in the first phase, followed by the collection and analysis of qualitative data in the second stage which is built based on initial quantitative results.

In qualitative research, the process of data collection and data analysis can be done simultaneously and then continued after the data has been collected [8]. Checking the validity of the data is an essential part and is an integral and inseparable part of qualitative research [9]. The implementation of inspection techniques is based on some specific criteria, there are four criteria used, namely the degree of trust (credibility), transferability, dependability, and certainty (confirmability) [10].

A population is a large group desired by researchers to be generalized based on the results of the sample [11]. The population in research is used to refer to a family or group of objects that are targeted for research in the form of humans, animals, plants, air, symptoms, values, events, life attitudes, etc. so that the object can be a source of research data [12]. The population in the study was economic teachers in the city of Banda Aceh. The teacher in question is an economics teacher at a high school who has an education certificate or who does not have an educator certificate.

A research instrument is a tool used by researchers to obtain data and information, then Likert scale questionnaires and others are used. The Likert scale is used to measure teachers' perceptions of the adoption of standard processes in economic teaching. Likert scale is a scale that can show the criteria of the respondent's attitude towards an object of study (always $=4$, often=3, rarely=2, and never=1). Information obtained by the Likert scale is an ordinal measurement scale. Therefore, the results can only be ranked without knowing how much difference between one response to another. The Likert scale used in this study uses four levels of response. The use of these four levels of response refers to Somantri and Muhidin, who argue that the Likert scale does not allow the existence of neutral statements so that there are only two statements on the Likert scale, namely positive and negative statements [13]. It is intended that the respondent gives a definite answer to an object being observed. Some related research has also used the Likert scale to be able to observe the attitudes of respondents [14; $15 ; 16]$.

\section{Results and discussion}

\subsection{Teaching Process Standards}

The standard teaching process is the primary measure of the preparation of teaching plans that are made to guide teaching in schools. The preparation of the Teaching Process Plan is explained in Figure 1. 


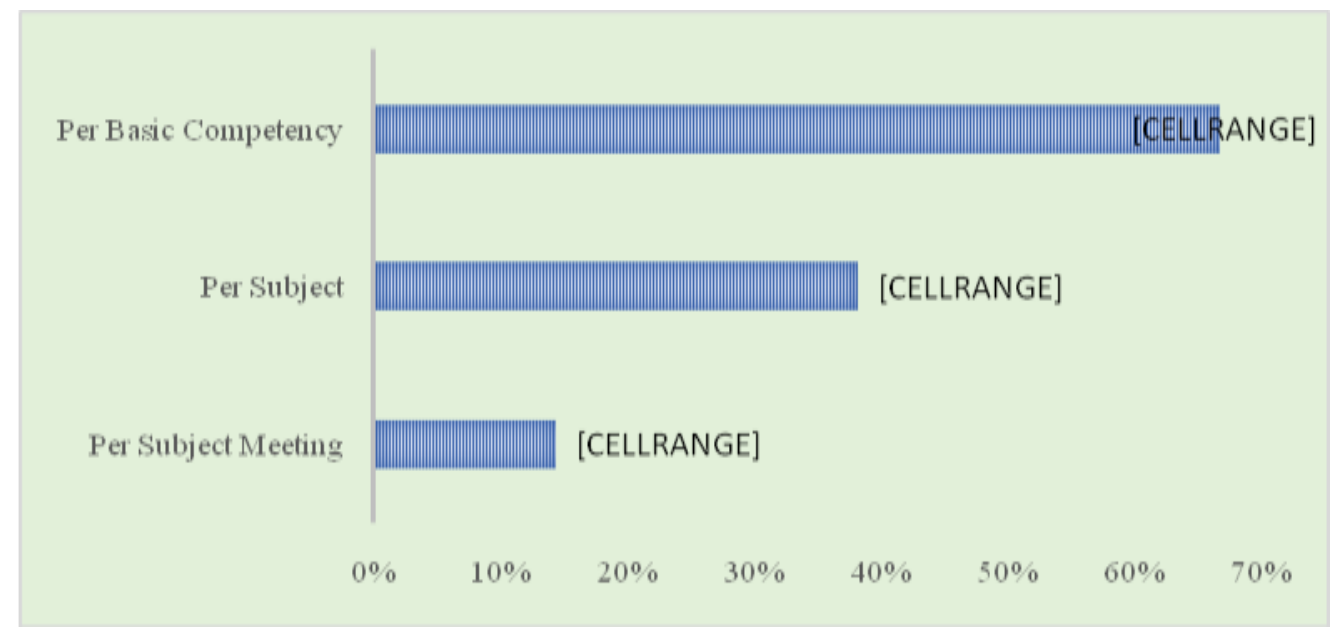

Fig. 1. Form of teaching implementation plan compiled by the teacher

Based on the way the teaching plan is compiled, most of the teachers, namely 67 percent of the teachers, have made a teaching implementation plan based on per basic competency, then as many as 38 percents of other teachers compile an implementation plan of teaching based on subjects. While some others prepare to teach implementation plans per meeting. Mapping core competencies - necessary competencies carried out in and across subjects. Furthermore, most respondents always make adjustments between core competencies - basic competencies are carried out with indicators, and adjustments are always made between indicators and material. Likewise, adjustments are always made between indicators, materials and teaching steps.

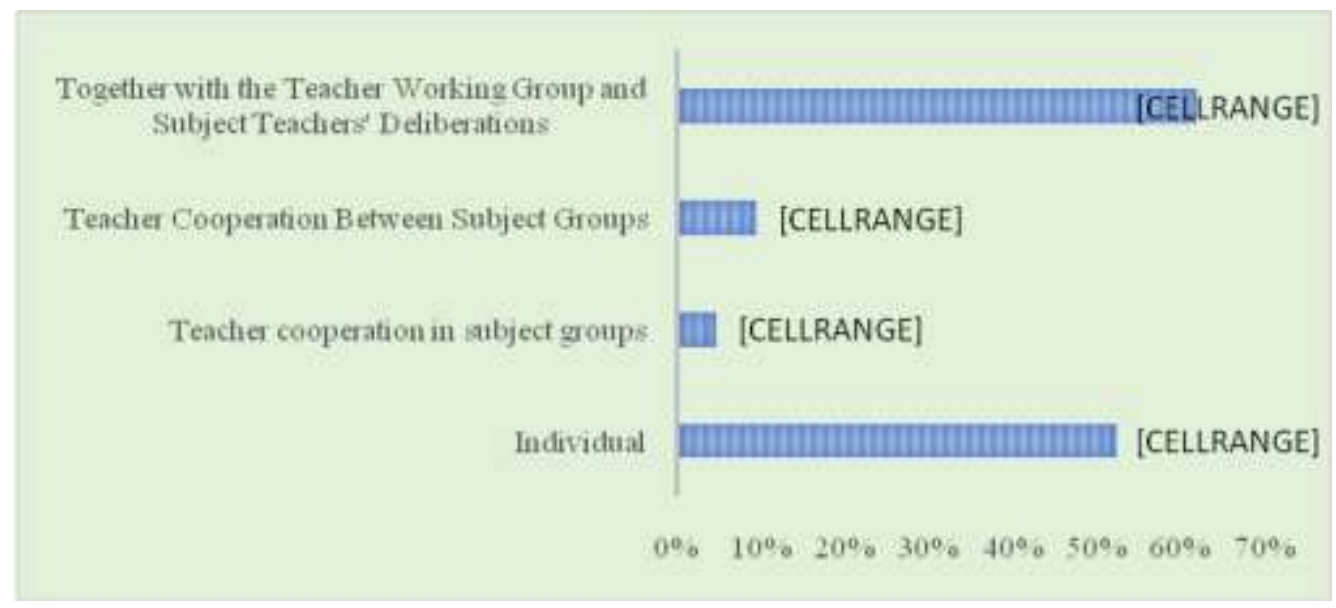

Fig. 2. Patterns in Developing Teaching Implementation Plans

The pattern of preparing a lesson plan prepared by the teacher is explained in Figure 2. Where, as many as 62 percent of respondents prepared a Teaching Implementation Plan carried out together in a teacher working group/subject teacher discussion forum, and 52 
percent of respondents said they prepared an individual teaching plan. Preparation of teaching implementation plans carried out through collaboration between subject groups and subject group collaboration is only done by 10 percent and 5 percent of respondents, respectively.

\subsection{Teaching implementation process}

The first teacher activity to do in the process of implementing teaching is to open the lesson. The expertise of a teacher carrying out these activities will determine the teaching process in the next phase. Respondents' responses to activities carried out by teachers in schools when opening teaching are presented in Table 1.

Table 1. Activities carried out by teachers at school when opening teaching

\begin{tabular}{|c|c|c|c|c|c|c|c|c|}
\hline \multirow{2}{*}{ No } & \multirow{2}{*}{ Statement } & \multicolumn{4}{|c|}{ Score } & \multicolumn{2}{|c|}{ Total Score } & \multirow{2}{*}{$\begin{array}{c}\% \\
\text { Current } \\
\text { Score }\end{array}$} \\
\hline & & Never & Rarely & Often & Always & $\begin{array}{l}\text { Current } \\
\text { Score }\end{array}$ & Never & \\
\hline 1 & $\begin{array}{l}\text { Invite students to carry out } \\
\text { pickets alternately }\end{array}$ & 2 & 4 & 21 & 40 & 67 & 84 & 79.76 \\
\hline 2 & $\begin{array}{l}\text { Ask a student to lead greetings } \\
\text { respectfully to the teacher }\end{array}$ & 0 & 0 & 21 & 56 & 77 & 84 & 91.67 \\
\hline 3 & $\begin{array}{l}\text { Invite students to read books } \\
\text { other than subject books for } \\
15 \text { minutes every day }\end{array}$ & 1 & 18 & 27 & 8 & 54 & 84 & 64.29 \\
\hline 4 & $\begin{array}{l}\text { Start the teaching process } \\
\text { according to the scheduled } \\
\text { time }\end{array}$ & 0 & 0 & 18 & 60 & 78 & 84 & 92.86 \\
\hline 5 & $\begin{array}{l}\text { Explain the syllabus of } \\
\text { subjects at the beginning of } \\
\text { each semester to students }\end{array}$ & 0 & 14 & 27 & 20 & 61 & 84 & 72.62 \\
\hline 6 & $\begin{array}{l}\text { Delivering the outline of the } \\
\text { scope of material and } \\
\text { activities to be carried out } \\
\text { according to the syllabus }\end{array}$ & 0 & 2 & 27 & 44 & 73 & 84 & 86.90 \\
\hline 7 & $\begin{array}{l}\text { Explain the teaching } \\
\text { objectives or basic } \\
\text { competencies to be achieved }\end{array}$ & 0 & 0 & 27 & 48 & 75 & 84 & 89.29 \\
\hline 8 & $\begin{array}{l}\text { Discuss previous } \\
\text { competencies related to } \\
\text { competencies that will be } \\
\text { studied and developed }\end{array}$ & 0 & 10 & 18 & 40 & 68 & 84 & 80.95 \\
\hline 9 & $\begin{array}{l}\text { Motivate students to apply } \\
\text { competencies to be achieved } \\
\text { in everyday life }\end{array}$ & 0 & 8 & 9 & 56 & 73 & 84 & 86.90 \\
\hline 10 & $\begin{array}{l}\text { Presenting the scope and } \\
\text { assessment techniques to be } \\
\text { used }\end{array}$ & 0 & 10 & 27 & 28 & 65 & 84 & 77.38 \\
\hline Tota & Current Score / Total Maximum & ore / Per & tage of 7 & al Curr & Score & 691 & 840 & 82.26 \\
\hline
\end{tabular}

Source: Primary Data, 2019

Based on Table 1 above shows that the ratio of the total acquisition of scores on teacher activities when opening lessons is 82.26 percent. This shows that the achievement of the score is in the top interval category. In other words, the council of teachers has been able to carry out activities to open lessons very well. Each score was contributed by the activity of the teacher who started the teaching process according to the scheduled time with a score ratio of 
92.86 percent; the teacher asks a student to lead the greeting to the teacher with a Current Score ratio of 91.67 percent; Explain the teaching objectives or basic competencies that will be achieved by achieving a score of 89.29 percent; Delivering the outline of the range of material and activities to be carried out according to the syllabus, and motivating students to apply the competencies to be achieved in daily life, each getting a score of 86.90 percent.

Furthermore, the score to discuss previous competencies is related to the competencies to be studied and developed with a score of 80.95 percent. Invite students to carry out pickets alternately with a score of 79.76 percent. Explain the syllabus of subjects at the beginning of each semester to students, and Invite students to read books other than subject books for 15 minutes every day, each having a score of 72.62 percent and 64.29 percent. The teacher's activity in the next stage after doing the activity of opening a lesson is to carry out teaching. The expertise of a teacher carrying out these activities will determine the teaching process in the next phase. The response of respondents' to the activities that teachers do at school when opening teaching are presented in Table 2.

Table 2. Activities carried out by the teacher in your school when carrying out teaching

\begin{tabular}{|c|c|c|c|c|c|c|c|c|}
\hline \multirow{2}{*}{ No } & \multirow{2}{*}{ Statement } & \multicolumn{4}{|c|}{ Score } & \multicolumn{2}{|c|}{ Total Score } & \multirow{2}{*}{$\begin{array}{c}\% \\
\text { Current } \\
\text { Score }\end{array}$} \\
\hline & & Never & Rarely & Often & Always & $\begin{array}{l}\text { Current } \\
\text { Score }\end{array}$ & Never & \\
\hline 1 & $\begin{array}{l}\text { Invite students to observe or } \\
\text { identify }\end{array}$ & 0 & 8 & 18 & 44 & 70 & 84 & 83.33 \\
\hline 2 & $\begin{array}{l}\text { Demonstrate skills or present } \\
\text { information step by step }\end{array}$ & 0 & 10 & 24 & 32 & 66 & 84 & 78.57 \\
\hline 3 & $\begin{array}{l}\text { Encourage students to ask } \\
\text { questions and express } \\
\text { opinions }\end{array}$ & 0 & 0 & 21 & 56 & 77 & 84 & 91.67 \\
\hline 4 & $\begin{array}{l}\text { Examine and provide input on } \\
\text { students' abilities }\end{array}$ & 0 & 2 & 30 & 40 & 72 & 84 & 85.71 \\
\hline 5 & $\begin{array}{l}\text { Prepare exercises for students } \\
\text { to apply the concepts learned } \\
\text { in everyday life }\end{array}$ & 0 & 8 & 39 & 16 & 63 & 84 & 75.00 \\
\hline 6 & Helping students form groups & 0 & 0 & 30 & 44 & 74 & 84 & 88.10 \\
\hline 7 & $\begin{array}{l}\text { Encourage students to gather } \\
\text { appropriate information }\end{array}$ & 0 & 0 & 21 & 56 & 77 & 84 & 91.67 \\
\hline 8 & $\begin{array}{l}\text { Encourage students to get an } \\
\text { explanation }\end{array}$ & 0 & 8 & 18 & 44 & 70 & 84 & 83.33 \\
\hline 9 & $\begin{array}{l}\text { Encourage students to take } \\
\text { advantage of teaching } \\
\text { resources that exist in school } \\
\text { and outside of school }\end{array}$ & 0 & 8 & 18 & 44 & 70 & 84 & 83.33 \\
\hline 10 & $\begin{array}{l}\text { Helping students reflect or } \\
\text { evaluate their investigation }\end{array}$ & 0 & 4 & 33 & 32 & 69 & 84 & 82.14 \\
\hline \multicolumn{6}{|c|}{ Total Current Score / Total Maximum Score / Percentage of Total Current Score } & 495 & 588 & 84.18 \\
\hline
\end{tabular}

Source: Primary Data, 2019

From a total of 10 items, the statement shows that the teacher's activities, when carrying out teaching related to the activity encourage students to ask questions and express opinions and encouraging students to gather appropriate information, each getting a score of 91.67 percent each. Furthermore, the lowest score is found in the teacher's activities in preparing exercises for students to apply the concepts learned in daily life, which is 75 percent. The 
scores in the statement above are in the proper and excellent ranges. If the score is totaled, the statement above is in the range of excellent scores. Respondents' responses to activities carried out by teachers at school when closing teaching are presented in Table 3.

Table 3. Activities carried out by the teacher when closing the teaching

\begin{tabular}{|c|c|c|c|c|c|c|c|c|}
\hline \multirow{2}{*}{ No } & \multirow{2}{*}{ Statement } & \multicolumn{4}{|c|}{ Score } & \multicolumn{2}{|c|}{ Total Score } & \multirow{2}{*}{$\begin{array}{c}\% \\
\text { Current } \\
\text { Score }\end{array}$} \\
\hline & & Never & Rarely & Often & Always & $\begin{array}{c}\text { Current } \\
\text { Score }\end{array}$ & Never & \\
\hline 1 & $\begin{array}{l}\text { Reflecting or evaluating with } \\
\text { students on their investigation }\end{array}$ & 0 & 6 & 24 & 40 & 70 & 84 & 83.33 \\
\hline 2 & $\begin{array}{l}\text { Give credit for individual or } \\
\text { group teaching efforts or } \\
\text { results }\end{array}$ & 1 & 10 & 24 & 28 & 63 & 84 & 75.00 \\
\hline 3 & $\begin{array}{l}\text { Perform follow-up activities } \\
\text { in the form of assigning tasks, } \\
\text { both individual and group } \\
\text { assignments }\end{array}$ & 0 & 4 & 24 & 44 & 72 & 84 & 85.71 \\
\hline 4 & $\begin{array}{l}\text { Inform the plan of teaching } \\
\text { activities for the next meeting }\end{array}$ & 0 & 6 & 24 & 40 & 70 & 84 & 83.33 \\
\hline 5 & $\begin{array}{l}\text { Invite to pray together under } \\
\text { their respective beliefs }\end{array}$ & 0 & 2 & 18 & 56 & 76 & 84 & 90.48 \\
\hline 6 & $\begin{array}{l}\text { End the teaching process } \\
\text { according to the scheduled } \\
\text { time }\end{array}$ & 0 & 0 & 21 & 56 & 77 & 84 & 91.67 \\
\hline \multicolumn{6}{|c|}{ Total Current Score / Total Maximum Score / Percentage of Total Current Score } & 428 & 504 & 84.92 \\
\hline
\end{tabular}

Source: Primary Data, 2019

Based on Table 3 above, the activities that teachers always carry out in closing teaching at school are reflecting or evaluating with students on their investigations, informing the plan of teaching activities for the next meeting, asking to pray together in accordance with their respective beliefs, and ending the teaching process according to the scheduled time. Overall for the activities undertaken by teachers when closing teaching in schools, the ratio of scores is 84.92 percent. The score ratio illustrates that the statement is in the first category or in general, the activities carried out by the teacher when closing teaching at school has been done very well.

\subsection{Assessment of teaching outcomes}

Respondents' responses to student skills achievement were submitted in five activity statements. These activities can be seen in Table 4.From the total of 5 items statement shows that the teacher's activities when carrying out teaching, related to the achievement of students' skills gained a score of 72.62 percent or in the excellent category. The highest score ratio is on the achievement of student skills related to conveying ideas and opinions politely and quickly understood (79.76 percent). Furthermore, the lowest score is found in the achievement of students' skills related to making papers with descriptions that are continuous and easy to understand (59.52 percent). 
Table 4. Respondents' Perceptions of Student Skill Achievement

\begin{tabular}{|c|c|c|c|c|c|c|c|c|}
\hline \multirow[b]{2}{*}{ No } & \multirow[b]{2}{*}{ Statement } & \multicolumn{4}{|c|}{ Score } & \multicolumn{2}{|c|}{ Total Score } & \multirow{2}{*}{$\begin{array}{c}\% \\
\text { Current } \\
\text { Score }\end{array}$} \\
\hline & & Never & Rarely & Often & Always & $\begin{array}{c}\text { Current } \\
\text { Score }\end{array}$ & Never & \\
\hline 1 & $\begin{array}{l}\text { convey ideas and opinions } \\
\text { politely and easily understood }\end{array}$ & 0 & 2 & 45 & 20 & 67 & 84 & 79.76 \\
\hline 2 & $\begin{array}{l}\text { listen to information } \\
\text { appropriately and relay it in } \\
\text { your own words }\end{array}$ & 0 & 4 & 54 & 4 & 62 & 84 & 73.81 \\
\hline 3 & $\begin{array}{l}\text { Do writing with descriptions } \\
\text { that are continuous and easy } \\
\text { to understand }\end{array}$ & 0 & 28 & 18 & 4 & 50 & 84 & 59.52 \\
\hline 4 & students ask critically & 0 & 12 & 33 & 16 & 61 & 84 & 72.62 \\
\hline 5 & $\begin{array}{l}\text { write in your language and } \\
\text { style }\end{array}$ & 0 & 6 & 39 & 20 & 65 & 84 & 77.38 \\
\hline \multicolumn{6}{|c|}{ Total Current Score / Total Maximum Score / Percentage of Total Current Score } & 305 & 420 & 72.62 \\
\hline
\end{tabular}

Source: Primary Data, 2019

\subsection{Supervision of the teaching process}

The examination time for the lesson plan is explained in Figure 3 below. Based on Figure 3 , the time for the examination of the lesson plan is mostly carried out by the principal in each semester (95 percent). Whereas school supervisors more often check the implementation plan of teaching every month (57 percent), and what is done in each semester is only 38 percent. On the other hand, only 5 percent of respondents stated that the school principal and school supervisor carried out effective every day, and another 5 percent said that the principal examined the lesson plan every week.

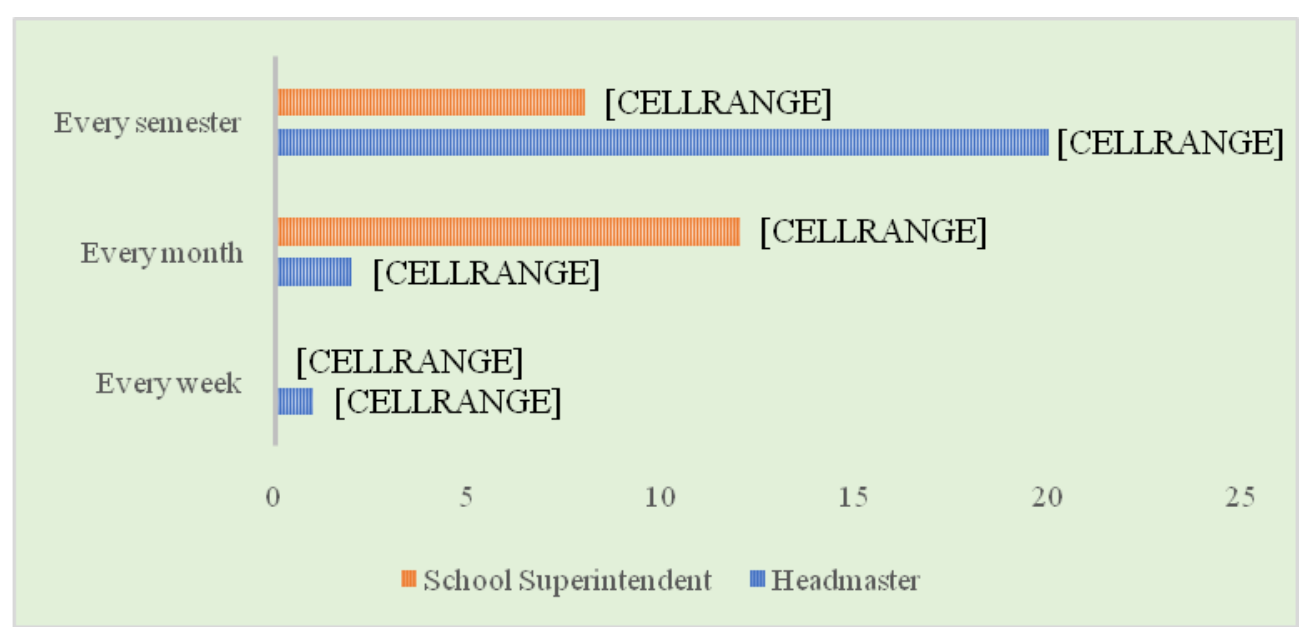

Fig. 3. Timing of the teaching implementation plan 


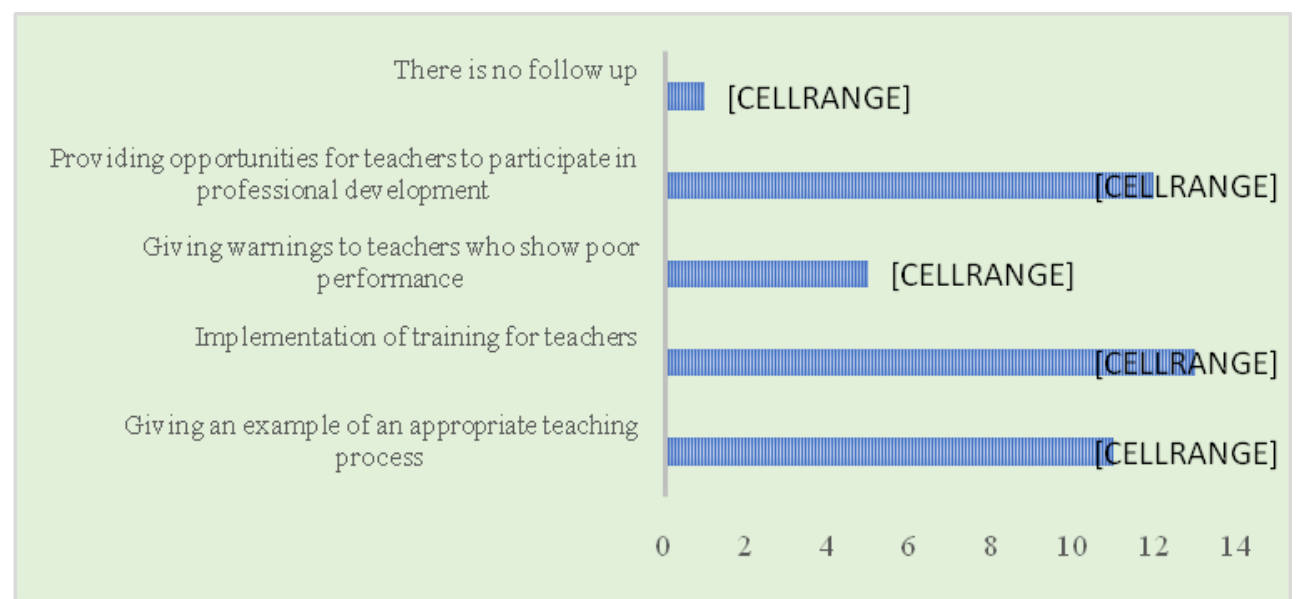

Note: 1 . Give examples of suitable teaching processes; 2. Implementation of training for teachers; 3. Giving warnings to teachers who show poor performance; 4. Providing opportunities for teachers to participate in professional development; and 5. There is no follow up.

Fig. 4. Follow-up on the results of monitoring the teaching process

The form of follow-up to the results of monitoring the teaching process carried out in your school is presented in Figure 4 where as much as 62 percent of respondents stated that the form of follow-up to the teaching process was carried out through the implementation of training to teachers, 57 percent of respondents stated through giving opportunities to teachers to participate in professional development, 52 percent of respondents stated through giving examples of appropriate teaching processes, 38 percent of respondents stated through conducting discussions on appropriate teaching processes, 24 percent of respondents stated through giving warnings / penalties to teachers who showed poor performance, 10 percent of respondents each stated through giving consultancy services for the teaching process and reinforcement to teachers who show performance meets or exceeds. While 5 percent of other respondents said, there was no follow up. Thus it can be concluded that in general the followup of the teaching process has been carried out by teachers in schools.

\section{Conclusions}

Based on the results of research and discussion, it can be concluded that the activities carried out by the teacher when opening a lesson are included in both categories. This can be seen including: (a) the timeliness of starting the teaching process; (b) students always lead respect greetings to the teacher; (c) the teacher explains the teaching objectives or basic competencies to be achieved; (d) the teacher also presents an outline of the scope of the material and activities to be carried out according to the syllabus; (e) and motivate students to apply the competencies to be achieved in everyday life.

The teacher's activity in the next stage is to carry out teaching. The expertise of a teacher carrying out these activities will determine the teaching process in the next phase. At this stage, the teacher has carried out teaching well. Among them, the teacher always encourages students to gather information accordingly, and the teacher also often proposes projects that will be done by students. Activities that are always done by teachers in closing teaching at school are doing reflection or evaluation with students of their investigations, evaluating the whole set of teaching activities and the results obtained with students, helping students find 
the benefits of teaching outcomes that have taken place, giving feedback to teaching process and results, conduct follow-up activities in the form of assignments, both individual and group assignments, inform the teaching plan for the next meeting, invite to pray together in accordance with their respective beliefs, and end the teaching process according to the scheduled time. In general, the activities undertaken by teachers when closing teaching at school have illustrated the activities done by teachers when closing teaching at school has been done well.

Although in general, the adoption of standard processes in economic teaching by teachers has been carried out well. However, efforts for teacher development must be carried out continuously both for teachers who have not yet received a professional teaching certificate or for teachers who have received certificates as professional teachers. This has also been recommended by the World Bank, including (1) building structured training with a focus on class needs; (2) building a system that can ensure that teachers master the competencies needed at higher levels of achievement throughout their careers [17].

Acknowledgments. Universitas Syiah Kuala funded this project research through the Lector Research grant scheme [contract number: 522/UN11/SPK/PNPB/2019].

\section{References}

[1] Republik Indonesia, "Undang-Undang Republik Indonesia Nomor 20 Tahun 2003 tentang Sistem Pendidikan Nasional." Sekretariat Negara, Jakarta, 2003.

[2] S. Žižek, “A permanent economic emergency," New Left Rev., vol. 64, no. 1, pp. 8595, 2010.

[3] Republik Indonesia, "Peraturan Menteri Pendidikan Nasional Republik Indonesia Nomor 41 Tahun 2007 tentang Standar Proses untuk Satuan Pendidikan Dasar dan Menengah." Sekretariat Negara, Indonesia, 2007.

[4] E. M. Rogers, Diffusion of Innovations. New York: Simon and Schuster, 2010.

[5] Republik Indonesia, "Peraturan Pemerintah Nomor 19 Tahun 2005 tentang Standar Nasional Pendidikan." Sekretariat Negara, Jakarta, 2005.

[6] L. Halimah, R. D. Rostika, and E. Sudirjo, "Pengembangan Model Penyusunan Kurikulum Tingkat Satuan Pendidikan (KTSP) yang Mengacu pada Standar Nasional Pendidikan," J. Penelit. Pendidik., vol. 10, no. 2, pp. 1-18, 2009.

[7] J. W. Creswell, "Research Design: Pendekatan Kualitatif, Kuantitatif, dan Mixed." Pustaka Belajar, Yogyakarta, 2010.

[8] M. B. Miles and A. M. Huberman, Analisis Data Kualitatif. Jakarta: UI Press, 1992.

[9] L. J. Moleong, Metodologi penelitian kualitatif. Bandung: Remaja Rosdakarya, 2007.

[10] S. Nasution, Metode Research (penelitian ilmiah). Jakarta: Bumi Aksara.

[11] B. Johnson and L. Christensen, Educational research: Quantitative, qualitative, and mixed approaches. Boston: Pearson Education.

[12] B. Bungin, Metodologi penelitian kuantitatif, komunikasi, Ekonomi, dan kebijakan publik Serta ilmu sosial lainnya. Jakarta: Kencana Prenada Media Group.

[13] A. Somantri and S. A. Muhidin, Somantri, A., \& Muhidin, S. A. (2006). Analisis Korelasi, Regresi, dan Jalur. Bandung: Penerbit Pustaka Setia, 2006.

[14] C. M. Rubie-Davies, A. Flint, and L. G. McDonald, "Teacher beliefs, teacher characteristics, and school contextual factors: What are the relationships?," Br. J. Educ. Psychol., vol. 82, no. 2, pp. 270-288, 2012.

[15] M. M. Van Wyk, "Do Student Teams Achievement Divisions Enhance Economic Literacy? A Quasi-experimental Design," J. Soc. Sci., vol. 23, no. 2, pp. 83-89, 2010. 
[16] M. M. van Wyk, "The Effects of the STAD-Cooperative Learning Method on Student Achievement, Attitude and Motivation in Economics Education," J. Soc. Sci., vol. 33, no. 2, pp. 261-270, 2012.

[17] M. C. Chang, S. Shaeffer, S. Al-Samarrai, A. B. Ragatz, J. de Ree, and R. Stevenson, Teacher Reform in Indonesia: The Role of Politics and Evidence in Policy Making. Washington, DC: World Bank, 2013. 